\title{
DIFFERENCES IN HUMAN MESENCHYMAL STEM CELL SECRETOMES DURING CHONDROGENIC INDUCTION
}

\author{
O.F.W. Gardner ${ }^{1,2}$, N. Fahy ${ }^{1}$, M. Alini ${ }^{1}$ and M.J. Stoddart ${ }^{1 *}$ \\ ${ }^{1}$ AO Research Institute, Davos, Switzerland. \\ ${ }^{2}$ School of Biosciences, Cardiff University, Cardiff, UK.
}

\begin{abstract}
Mesenchymal stem cells (MSCs) can be induced towards chondrogenesis through the application of chondrogenic stimuli such as transforming growth factor- $\beta$ (TGF- $\beta$ ) or by multiaxial mechanical load. Previous work has showed that the chondrogenic effect of multiaxial load on MSCs is mediated by the endogenous production of TGF- $\beta 1$ by stimulated cells. This work compared the effects of TGF- $\beta 1$ stimulation and multiaxial mechanical load on the secretomes of stimulated cells. MSCs were seeded into fibrin-poly(ester-urethane) scaffolds and chondrogenically stimulated with either TGF- $\beta 1$ or mechanical load. The culture media was collected and analysed for 174 proteins using a cytokine antibody array. The results of the secretome analysis were then confirmed at a gene expression level by real-time PCR. As results implicated nitric oxide (NO), the media nitrite content was also determined as an indirect measurement of media NO levels. Results showed that TGF- $\beta 1$ stimulation and mechanical load lead to similar changes in factors such as BLC, VEGF and MMP13, whilst differences in detected levels were seen for factors including leptin, MDC, MIP3 $\alpha$ and LAP. Gene expression analysis confirmed significant changes in four factors: angiopoietin 2, GRO $\alpha$, MMP13 and osteoprotegerin. After one week in culture the media nitrite content was significantly higher in loaded groups than both control and TGF- $\beta 1$ stimulated groups, suggesting this may be a major therapeutic target. These data show that despite clear similarities, TGF- $\beta 1$ stimulation and load have distinct effects on MSCs and are not analogous. This study has identified a number of potentially novel targets for tissue engineering, these data may also be useful for improving rehabilitation protocols e.g. after microfracture.
\end{abstract}

Keywords: Secretome, paracrine signalling, regenerative medicine, cartilage repair, cytokines.

* Address for correspondence:

Prof. Martin J. Stoddart,

AO Research Institute Davos,

Clavadelerstrasse 8 ,

7270 Davos Platz,

Switzerland,

Telephone Number: 0041-81-414-2448

FAX Number: 0041-84-414-2288

E-mail: martin.stoddart@aofoundation.org
ALCAM - Activated leukocyte cell adhesion molecule aMEM - Alpha minimal essential medium

BLC - B lymphocyte chemoattractant

BMP - Bone morphogenic protein

DMEM - Dulbecco's modified Eagle medium

DR6 - Death receptor 6

FBS - Foetal bovine serum

GRO - Growth related oncogene

hBMSC - Human bone marrow derived stem cell

LAP - Latency associated peptide

MDC - Macrophage derived chemokine

MIF - Macrophage migration inhibitory factor

MIP3 $\alpha$ - Macrophage inflammatory protein 3 alpha

MMP13 - Matrix metalloproteinase 13

MSC - Mesenchymal stem cell

$\mathrm{NO}$ - Nitric oxide

OPG - Osteoprotegerin

PCR - Polymerase chain reaction

PDGF - Platelet derived growth factor

TGF- $\beta$ - Transforming growth factor beta.

TIMP - Tissue inhibitor of metalloproteinase

UPAR - Urokinase receptor

VEGF - Vascular endothelial growth factor

\section{Introduction}

Currently, standard protocols for the induction of chondrogenesis in human mesenchymal stem cells (MSCs) in vitro involve the culture of cells in a $3 \mathrm{D}$ environment (e.g. in a pellet/micromass culture or encapsulated with in a hydrogel) coupled with the exogenous application of an isoform of TGF- $\beta$ (Barry et al., 2001; Johnstone et al., 1998). This chondrogenic response is induced by TGF- $\beta$ and mediated by SMAD signalling proteins, which results in an increase in the expression of chondrogenic markers such as the transcription factor Sox 9 and the matrix molecules aggrecan and type II collagen (Furumatsu et al., 2005; Hellingman et al., 2011; Johnstone et al., 1998). Following chondrogenesis, both in vitro (Johnstone et al., 1998) and in vivo (Mueller and Tuan, 2008), MSCs have a tendency to progress towards hypertrophy, which is marked by the expression of molecules such as collagen type X and MMP13 (D'Angelo et al., 2001; D'Angelo et al., 2000; Johansson et al., 1997). This progression of MSCs from a cartilage producing phenotype into a hypertrophic phenotype is reminiscent of the behaviour of mesenchymal progenitor cells during bone formation through endochondral ossification and presents a major barrier to the use of MSCs for the clinical repair of cartilage 
tissue (Goldring et al., 2006; Mackie et al., 2011; Mueller and Tuan, 2008; Sheehy et al., 2015).

Previous work has shown that chondrogenesis of human bone marrow derived MSCs can be induced in the absence of exogenous recombinant TGF- $\beta$ through the application of multiaxial load (Li et al., 2010b; Schatti et al., 2011). In this system multiaxial load refers to a combination of shear and compression, which mimics the loading of a diarthrodial joint in vivo (Grad et al., 2005; Wimmer et al., 2004). This combination of mechanical stimuli provides an in vitro model for studying the response of constructs designed to facilitate cartilage repair in a simulated joint mechanical environment. Further investigation showed that the induction of chondrogenesis in this system is linked to the TGF- $\beta$ signalling pathway (Li et al., 2010a). The application of multiaxial load to MSCs seeded within fibrin-poly(ester-urethane) scaffolds leads to the endogenous production of TGF- $\beta 1$ by the cells, which then drives the chondrogenesis of cells within the scaffold. Blocking TGF- $\beta$ receptor 1 signalling prevents this induction of chondrogenesis in response to multiaxial mechanical load, showing that the endogenously produced TGF- $\beta 1$ acts through TGF- $\beta 1 \mathrm{R}$ to induce chondrogenesis in response to load ( $\mathrm{Li}$ et al., 2010a). However, it is not currently clear if load induced chondrogenesis is exclusively TGF- $\beta$ mediated.

MSCs are known to respond to specific stimuli by generating matrix molecules and adopting cellular characteristics associated with tissues such as bone, cartilage and adipose. In addition to these matrix molecules, MSCs also secrete a large number of bioactive factors (Caplan, 2007; Czekanska et al., 2014). These factors provide information on the phenotype of the cells producing them, as well mechanistic information about changes that occur in cells in response to certain stimuli. Crucially, a cell's secretome provides an indication of what effect the cell might have on endogenous cells in a clinical situation. The secretomes of MSCs are increasingly being studied (Stoddart et al., 2015) and the secretomes of MSCs from various sources have been investigated in a number of culture conditions in recent years (Haynesworth et al., 1996; Kinnaird et al., 2004; Liu and Hwang, 2005; Rehman et al., 2004; Sze et al., 2007). These studies have focused on different aspects of MSC biology including; angiogenesis, myogenesis and osteogenesis (De Lisio et al., 2014; Hoch et al., 2012; Oskowitz et al., 2011). A number of papers have also investigated the effects of chondrogenic stimulation on the MSC secretome (Arufe et al., 2011; Bara et al., 2014; Grassel et al., 2009; Rocha et al., 2014; Rodriguez et al., 2015). These studies have demonstrated the upregulation of factors such as VEGF, MMP13 and TIMP1 and 2. To the authors knowledge, no investigations have been made into the secretome of MSCs undergoing chondrogenesis in response to multiaxial load, or compared the secretomes of MSCs responding to mechanical load and TGF- $\beta 1$ stimulation.

The aim of this study was to compare the secretomes of unstimulated hBMSCs, hBMSCs cultured with TGF- $\beta 1$ in order to induce chondrogenesis, and hBMSCs cultured in the absence of TGF- $\beta 1$ but with multiaxial mechanical load in order to induce chondrogenesis. An early time point was investigated as it is relevant during the period of cell engraftment and the initiation of healing. It was hypothesised that by analysing the secretomes of MSCs cultured in different chondrogenic culture conditions, and in different mechanical environments, it would be possible to compare the effects of mechanical load and TGF- $\beta 1$ stimulation on the chondrogenic induction of hBMSCs in order to gain greater understanding of the response of cells to these two different stimuli. This knowledge could also be used to identify interesting and potentially novel factors for MSC based tissue engineering.

\section{Materials and Methods}

\section{MSC isolation, culture and scaffold seeding}

MSCs were harvested from bone marrow aspirates collected during routine operations with full-ethical approval (KEK-ZH-NR: 2010-0444/0). Mononuclear cells were isolated from whole bone marrow of three donors (males aged 22, 38 and 77 years old) collected from vertebral bodies using a Ficoll density separation method (Histoplaque-1077, Sigma-Aldrich, Buchs, Switzerland). Mononuclear cells were then seeded at a density of 50,000 cells $/ \mathrm{cm}^{2}$ and left to attach for $96 \mathrm{~h}$ in expansion medium consisting of alpha Minimum Essential Medium ( $\alpha \mathrm{MEM})$ (Gibco, Carlsbad, USA), $10 \%$ MSC screened foetal bovine serum (FBS) (Pan Biotech, Aidenbach, Germany), $5 \mathrm{ng} / \mathrm{mL}$ basic fibroblast growth factor (bFGF) (Peprotech, Rocky Hill, USA) and $1 \%$ penicillin/streptomycin (Gibco, Carlsbad, CA). Passage 1 MSCs were frozen and stored in liquid nitrogen. Proliferation of MSCs after storage was carried out using $\alpha$ MEM $10 \%$ FBS with $5 \mathrm{ng} / \mathrm{mL}$ bFGF. Passage 3 or 4 cells were seeded into $8 \mathrm{~mm} \times 2 \mathrm{~mm}$ fibrinpoly(ester-urethane) scaffolds (fibrin from Baxter, Vienna, Austria) as previously described (Li et al., 2009). Briefly, 2 million MSCs per scaffold were resuspended in $37.5 \mu \mathrm{L}$ of fibrin $(33 \mathrm{mg} / \mathrm{mL})$. The fibrin/cell mixture was then mixed with $37.5 \mu \mathrm{L}$ of thrombin $(0.5 \mathrm{U} / \mathrm{mL})$ before being infused in to a poly(ester-urethane) sponge and then left at $37^{\circ} \mathrm{C}$ $90 \%$ humidity and $5 \% \mathrm{CO}_{2}$ to cure.

\section{Culture conditions}

Three different culture conditions were used for this experiment. Constructs were either cultured in a free swelling environment with chondropermissive medium (consisting of Dulbecco's modified Eagle medium $4.5 \mathrm{~g} / \mathrm{L}$ glucose (Gibco, Carlsbad, USA), sodium pyruvate $0.11 \mathrm{~g} / \mathrm{L}$ (Sigma-Aldrich, Buchs, Switzerland), L-ascorbic acid 2-phosphate sesquimagnesium salt hydrate $50 \mu \mathrm{g} / \mathrm{mL}$ (Sigma-Aldrich, Buchs, Switzerland), dexamethasone $1 \times 10^{-7} \mathrm{M}$ (Sigma-Aldrich, Buchs, Switzerland), insulin transferrin and selenium $1 \%$ (Cyangen, Guangzhou, China), Non-essential amino acids $1 \%$ (Gibco, Carlsbad, USA), Primocin $0.1 \%$ (Invitrogen, San Diego, USA) and 6-aminocaproic acid $5 \mu \mathrm{M}$ (Sigma-Aldrich, Buchs, Switzerland) to prevent fibrin degradation (Kupcsik et al., 2009), a free swelling environment with chondropermissive medium supplemented with $1 \mathrm{ng} / \mathrm{mL}$ active TGF $\beta 1$ (Fitzgerald, Acton, USA), or with exposure to multiaxial loading in TGF $\beta$ free chondropermissive media. A 
concentration of $1 \mathrm{ng} / \mathrm{mL}$ was chosen for the TGF- $\beta 1$ stimulated group as media collected from mechanically loaded scaffolds consistently contain approximately $1 \mathrm{ng} /$ $\mathrm{mL}$ of endogenously produced TGF- $\beta 1$ (Li et al., 2010a). The medium was refreshed on day 2, 4 and 6 .

\section{Mechanical loading}

Multiaxial shear $( \pm 25$ at $1 \mathrm{~Hz})$ and compression (10\% compression superimposed on top of a $10 \%$ pre-strain at $1 \mathrm{~Hz}$ ) loading was applied for one hour a day six times over $8 \mathrm{~d}$ (on days 2-7) (Li et al., 2010a).

\section{Sample collection}

The work presented here represents data from two sets of experiments, each with the same experimental design. The first set of experiments consisted of three biological repeats, each using MSCs from a different donor (donors were aged 22,27 and $77 \mathrm{y}$ ). In the first set of experiments the culture media were collected on day 2, 4, 6 and 8 for TGF- $\beta 1$ quantification and secretome analysis. The second set of experiments was performed in order to collect additional data to supplement and confirm the results of the first set of experiments. This second set of experiments replicated the first, using cells from the same three MSC donors as the first experiment with the same passage number at the time of seeding. Culture media were collected on day 2, 4, 6 and 8 for nitrite quantification and on day 8 the scaffolds were homogenised in TRI reagent (Molecular Research Centre Inc., Cincinnati, OH, USA) and stored at $-80^{\circ} \mathrm{C}$ for RNA isolation and real-time PCR analysis.

\section{Culture media analysis}

Media collected on day eight of culture were further analysed to determine the presence of 174 different cytokines within each sample using the RayBio Human Cytokine Antibody Array G-Series 2000 protein array according to the manufacturer's instructions, for relevant abbreviations see Table 1. The slides were sent to THP Medical Products Vertreibs Gmbh (Vienna, Austria) for analysis.

The total amount of TGF- $\beta 1$ in the culture media collected between day 2 and day 8 was determined using the human TGF-beta 1 DuoSet ELISA (R\&D systems, Minneapolis, USA) according to the manufacturer's instructions

The Griess reaction to detect nitrite in collected culture media was performed using Griess reagent (modified) (Sigma) according to the manufacturer's instructions.

Table 1. The results of statistical comparisons made between groups. All factors that showed at least one significant change are included. A $p$-value displayed in red represents a decrease in expression in the group the comparison was made to (e.g. a red $p$-value in the 'TGF- $\beta 1$-load' column indicates a decrease in the TGF- $\beta 1$ stimulated group compared to the loaded group) whilst green represents an increase in expression in the group the comparison was made to (e.g. a green $p$-value in the 'TGF- $\beta 1$-control' column indicates an increase in the TGF- $\beta 1$ stimulated group compared to the control group). Abundance demonstrates the overall amount of protein in the medium based on the strength of signal detected during measurement, this is only arbitrary and acts as a general indicator of the amount of a particular protein relative to the others detected (the units are arbitrary and represent fluorescence intensity, Very low $<100$, low 100-500, moderate 500-1000, high 1000-4000 and very high $>4000)$.

\begin{tabular}{|c|c|c|c|c|}
\hline Factor name: & Abundance & $\begin{array}{c}\text { TGF- } \beta 1-C o n t r o l \\
p \text {-value }\end{array}$ & $\begin{array}{c}\text { Load-Control } \\
p \text {-value }\end{array}$ & $\begin{array}{c}\text { TGF- } \beta 1-L o a d \\
p \text {-value }\end{array}$ \\
\hline \multicolumn{5}{|c|}{ Factors with a Significant Difference in One Comparison } \\
\hline Leptin & Low & 0.0246 & 0.4757 & 0.6992 \\
\hline Leptin receptor & Low & 0.0144 & 0.9999 & 0.1721 \\
\hline Macrophage derived chemokine (MDC) & Very Low & 0.0378 & 0.3897 & 0.9813 \\
\hline $\begin{array}{l}\text { Chemokine (CC motif) ligand } 20 \text { (CCL20), macrophage inflammatory } \\
\text { protein } 3 \alpha(\mathrm{MIP} 3 \alpha)\end{array}$ & Very Low & 0.2550 & 0.032 & 0.9999 \\
\hline $\begin{array}{l}\text { Chemokine (CXC motif) ligand 1,2 and } 3 \text { (CXCL1,2 and 3), Growth } \\
\text { related oncogene } \alpha, \beta \text { and } \gamma(\mathrm{GRO} \alpha, \beta \text { and } \gamma)\end{array}$ & Moderate-High & 0.0749 & 0.0272 & 0.9999 \\
\hline Urokinase receptor (uPAR) & Low & 0.1820 & 0.0358 & 0.9999 \\
\hline Latency associated peptide (LAP) & Moderate & 0.1968 & 0.0001 & 0.0667 \\
\hline Angiogenin & High-Very High & 0.0526 & 0.0019 & 0.8959 \\
\hline Angiopoietin 2 (ANG2) & High & 0.7034 & 0.1869 & 0.0061 \\
\hline Osteoprotegrin (OPG) & Moderate-High & 0.9999 & 0.1573 & 0.0113 \\
\hline $\begin{array}{l}\text { Tumour necrosis factor receptor superfamily } 21 \text { (TNFRSF21), death } \\
\text { receptor } 6 \text { (DR6) }\end{array}$ & Low-Moderate & 0.4128 & 0.8959 & 0.0348 \\
\hline \multicolumn{5}{|c|}{ Factors with a Significant Difference in Two Comparisons } \\
\hline Transforming growth factor $\beta 1$ (TGF- $\beta 1$ ) & Low & 0.0157 & 0.9999 & 0.0411 \\
\hline $\begin{array}{l}\text { Cluster of differentiation } 166 \text { (CD166), activated leukocyte cell adhesion } \\
\text { molecule (ALCAM) }\end{array}$ & Low & 0.9999 & 0.0226 & 0.0378 \\
\hline $\begin{array}{l}\text { Chemokine (CXC) motif ligand } 13 \text { (CXCL13), B lymphocyte } \\
\text { chemoattractant (BLC) }\end{array}$ & Low-Moderate & 0.032 & 0.0002 & 0.4884 \\
\hline $\begin{array}{l}\text { Chemokine (CC motif) ligand } 7 \text { (CCL7), Monocyte specific chemokine } \\
3 \text { (MCP3) }\end{array}$ & Low & 0.0012 & 0.0089 & 0.9999 \\
\hline Macrophage migration inhibitory factor (MIF) & High & 0.0328 & 0.0001 & 0.2883 \\
\hline Vascular endothelial growth factor (VEGF) & Moderate-High & 0.0091 & 0.0091 & 0.9999 \\
\hline Matrix metalloproteinase 13 (MMP13), collagenase 3 & Low-Moderate & 0.0189 & 0.0010 & 0.9999 \\
\hline Platelet derived growth factor AA (PDGFAA) & Low & 0.004 & 0.0055 & 0.9999 \\
\hline
\end{tabular}


Briefly, $100 \mu \mathrm{L}$ of Griess reagent was added to $100 \mu \mathrm{L}$ of standards and samples. The reaction was allowed to proceed for $15 \mathrm{~min}$ in the dark before the absorbance was measured at $530 \mathrm{~nm}$.

\section{Reverse transcription and real-time PCR}

Total RNA was isolated on day 8 from samples in TRI reagent as per the manufacturer's instructions. Reverse transcription was performed using random hexamer primers and TaqMan reverse transcription reagents (Applied Biosystems, Carlsbad, CA, USA).

Real-time PCR was performed using the applied biosciences StepOnePlus real-time PCR system (Applied Biosystems, Carlsbad, CA, USA). Primers for VEGF mRNA were synthesised by Microsynth AG (Balgach, SG, Switzerland). Primers for angiogenin, angiopoietin 2, BLC, GRO $\alpha$, leptin, MCP3, MIF, MIP3 $\alpha$, MMP13, osteoprotegerin, PDGFA and ribosomal 18s RNA were purchased from Applied Biosystems, Switzerland. The level of gene expression for each gene was determined relative to $18 \mathrm{~s}$ rRNA using a $\Delta \Delta \mathrm{CT}$ comparison.

\section{Statistical analysis}

Statistical analysis was performed using GraphPad Prism 6 software (GraphPad Software Inc., La Jolla, USA). Results of TGF- $\beta 1$ quantification and secretome analysis represent data from three different MSC donors with each group containing three technical repeats. Results of nitrite quantification and real-time PCR analysis represent data from three biological repeats, with each group containing four technical repeats.

The fluorescent intensity levels recorded for each sample from the cytokine array were adjusted to remove background interference. Outliers were then removed using the ROUT method, normality was determined using the D'Agostino-Pearson omnibus normality test and the statistical difference was then determined between control and TGF- $\beta 1$ cultured groups, between load and control and between load and TGF- $\beta 1$ cultured groups using KruskalWallis test and Dunn's multiple comparison test.

The results of TGF- $\beta 1$ quantification, nitrite quantification and real-time PCR analysis were tested for normality using the D'Agostino-Pearson omnibus normality test. Statistical differences of media TGF- $\beta 1$, nitrite ions and all genes analysed by real-time PCR (except leptin and MMP13) were determined using the KruskalWallis test and Dunn's multiple comparison test. Statistical significance for leptin and MMP13 was determined using the Mann-Whitney test. $p \leq 0.05$ was considered to be significant.

\section{Results}

\section{TGF-ק1 quantification}

On day 2 the amount of TGF- $\beta 1$ measured in the culture medium of TGF- $\beta 1$ stimulated scaffolds was higher than both control and loaded groups $(p=0.0378)$ (Fig. 1A). This was expected, as the TGF- $\beta 1$ cultured group was receiving TGF- $\beta$ in the media at this point whilst the other two groups were not. At day 4 of culture (Fig. 1B), as mechanical loading began to induce the production of TGF- $\beta 1$ by the cells within the scaffold, the amount of TGF- $\beta 1$ in the media collected from TGF- $\beta 1$ stimulated scaffolds was significantly higher than that of the control group ( $p=0.0017$ ) but not significantly different from the loaded group. By day 6 of culture, multiaxial mechanical loading had led to a significant increase in TGF- $\beta 1$ production compared to control scaffolds and the level of TGF- $\beta 1$ in the media of both TGF- $\beta 1$ stimulated and loaded groups was significantly higher than that of the control group ( $p=0.0001$ and 0.0207 respectively). Both TGF- $\beta 1$ stimulated and load media also contained significantly more TGF- $\beta 1$ than control samples on day eight ( $p=0.0002$ and 0.0060 respectively).

\section{Cytokine detection}

All 174 factors were detected at varying levels of intensity in all samples. An average fluorescence intensity value was calculated for each factor at day 8 from all three conditions (control, load and TGF- $\beta 1$ stimulated) in order to provide a guide to the level of detection of the different factors across the groups, rather than in specific conditions. 55 factors had an average fluorescence intensity across the three groups of less than 100 including; leptin (93.79 $\pm 81.83)$ and $\mathrm{MDC}(54.81 \pm 9.98)$. The average intensity of 94 factors was between 100 and 500 including; BLC $(389.19 \pm 557.10)$, MCP3 $(201.30 \pm 115.94)$, ALCAM $(141.57 \pm 37.54)$, uPAR $(286.63 \pm 109.39)$, leptin receptor $(110.07 \pm 29.35)$, MMP13 $(422.77 \pm 512.66)$ and PDGFaa $(171.75 \pm 76.35)$. The intensity of 11 factors was between 500-1000 including; osteoprotegerin (986.16 \pm 560.48) and VEGF (938.11 \pm 397.31$)$. 12 factors had an average intensity between 1000 and 4000 including; angiopoietin-2 $(1341.87 \pm 937.81)$, GRO (1326.36 \pm 1011.64$)$ and LAP $(1302.15 \pm 752.86)$. The intensity of two factors was above 4000; angiogenin (40273.68 \pm 7037.95$)$ and TIMP2 $(6778.68 \pm 2231.98)$. The factor with the highest recorded intensity, by a factor of 10 , was angiogenin and the lowest was BMP6 $(20.50 \pm 18.21)$.

For each of the 174 factors analysed, three sets of comparisons were performed (between control and TGF- $\beta$ stimulated scaffolds, control and loaded scaffolds and TGF- $\beta 1$ stimulated and loaded scaffolds) and the significance of statistical differences between the groups determined. Analysis showed that 19 factors changed significantly in at least one of these comparisons. The three volcano plots in Fig. 2 graphically represent the results of these three comparisons. These plots were produced by plotting the Log 10 of the fold change for a factor between one condition and another (e.g. control and TGF- $\beta 1$ ) on the $\mathrm{X}$-axis, against the $-\log 10$ of the $p$-value generated when testing the difference between the two conditions on the Y-axis. Therefore, the further a factor is away from zero on the $\mathrm{X}$-axis the greater the fold change up or down. The further a factor is up the Y-axis the lower the $p$-value, a $p$-value of 0.05 equates to 1.30 on the Y-axis. Therefore, any factors above this value underwent a significant change.

Fig. 2A shows a volcano plot generated based on the comparison between media conditioned by TGF- $\beta 1$ stimulated scaffolds and control medium, factors that 

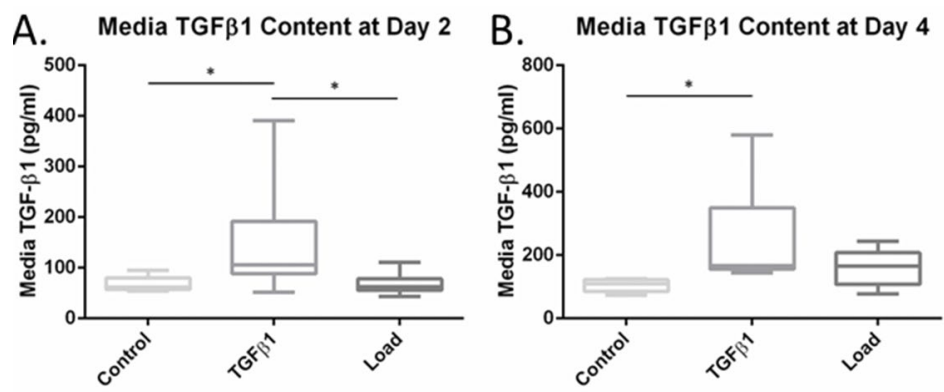

Fig. 1. Quantification of total TGF- $\beta 1$ in the culture media of control, TGF- $\beta 1$ stimulated and loaded scaffolds by week, over four weeks of culture. Statistical significance was defined as $p \leq 0.05$ and determined using the KurskalWallis and Dunn's multiple comparison tests. * represents $p \leq 0.05, * *$ represents $p \leq 0.001$ and $* * *$ represents $p \leq 0.0001$.

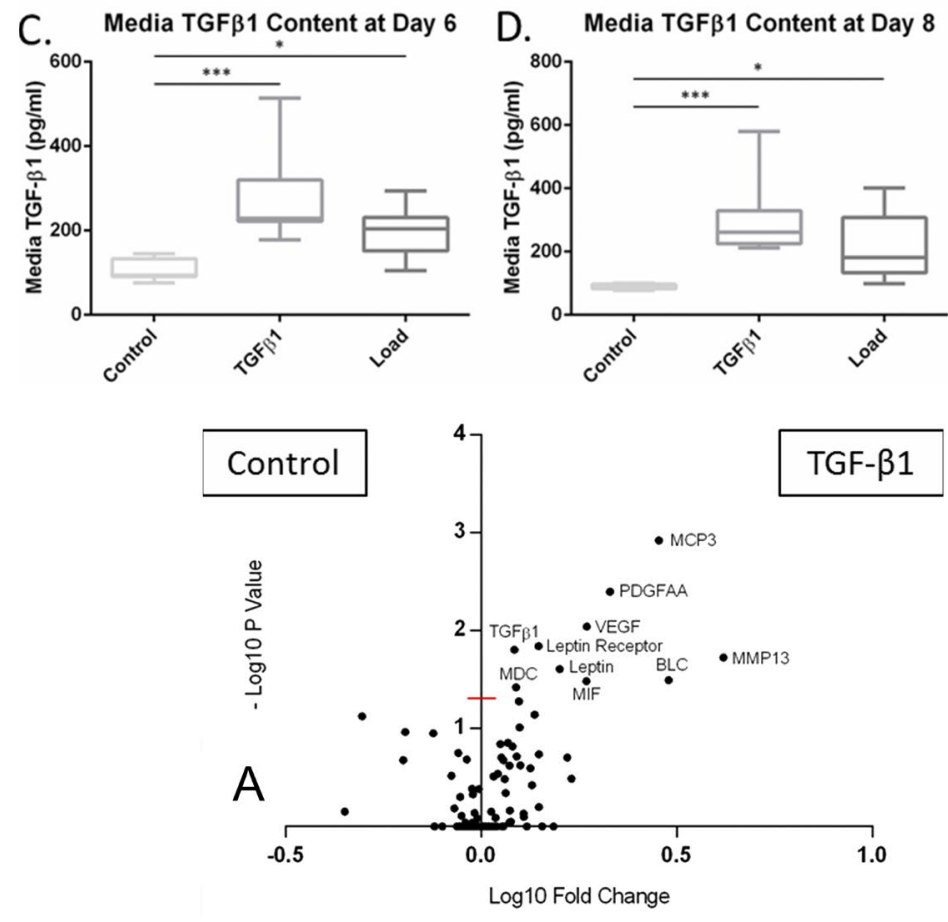

Fig. 2. Volcano plots showing the results of the three sets of statistical comparisons made between groups. These plots have $-\log 10 p$-value of the comparison on the Y-axis and $\log 10$ fold change of the comparison for each factor on the $\mathrm{X}$-axis. As a result the greater the fold change the further a factor is away from zero on the $\mathrm{X}$-axis and the lower the $p$-value of a comparison the further away from zero on the Y-axis. Factors that underwent a significant change have been labelled. The red line on the Y-axis represents $\mathrm{a}-\log 10 p$-value of 1.3 this is equivalent to a $p$-value of 0.05 , factors above this line underwent a significant change. Plot A. represents TGF- $\beta 1$ stimulated samples compared to controls. Factors on the left-hand side of the Y-axis were higher in controls than TGF- $\beta 1$ stimulated samples and factors on the right-hand side were higher in TGF- $\beta 1$ stimulated samples than controls.

Plot B. represents loaded samples compared to controls. Factors on the left had side of the Y-axis were higher in controls than loaded samples and factors on the right hand side were higher in loaded samples than controls.

Plot C. represents TGF- $\beta 1$ stimulated samples compared to loaded samples. Factors on the left hand side of the Y-axis were higher in loaded samples than TGF- $\beta 1$ stimulated samples and factors on the right hand side were higher in TGF- $\beta 1$ stimulated samples than loaded samples.
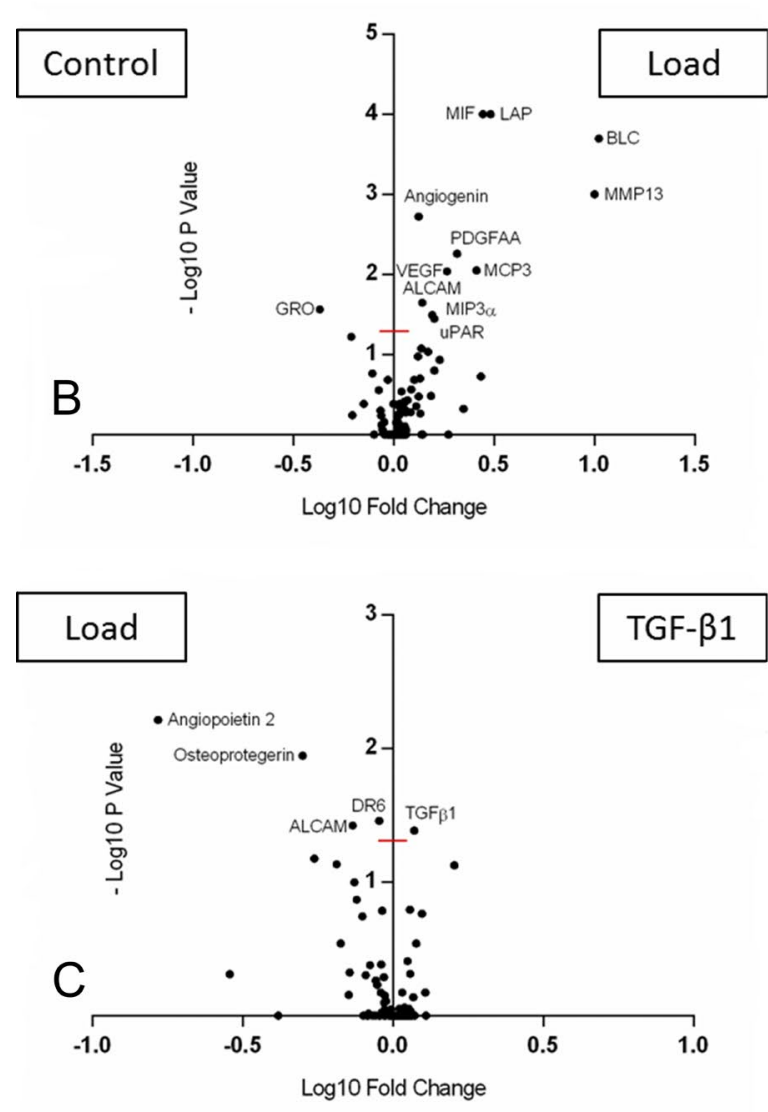

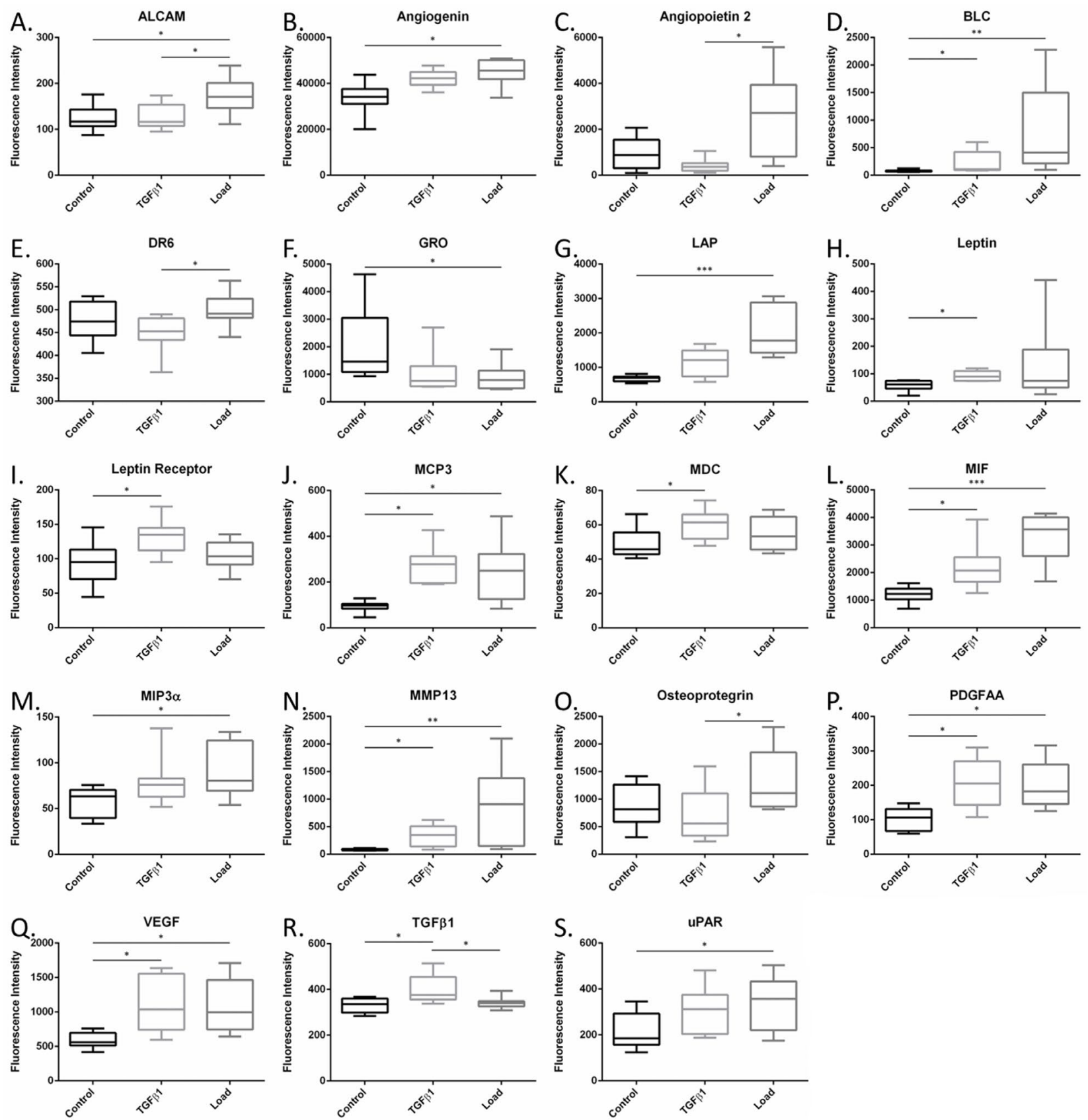

Fig. 3. Box plots showing the results of cytokine antibody array analysis. This figure contains the 19 factors that showed a significant change between in at least one comparison (the three comparisons were between control and TGF- $\beta 1$, between load and controls and load and TGF- $\beta 1$ ). Statistical significance was defined as $p \leq 0.05$ and determined using the Kurskal-Wallis and Dunn's multiple comparison tests. * represents $p \leq 0.05$, ** represents $p \leq 0.001$ and $* * *$ represents $p \leq 0.0001$.

appear on the left side of the Y-axis were detected at a higher level in control medium, and factors on the right hand side of the axis at a higher level in TGF- $\beta 1$ stimulated medium. Factors which are significantly different between control and TGF- $\beta 1$ stimulated medium have been labelled. Fig. $2 \mathrm{~B}$ shows a volcano plot constructed in the same way as Fig. 2A, using data from the comparison between control medium and medium conditioned by cells exposed to multiaxial load. Factors that appear on the left side of the Y-axis were detected at a higher level in control medium and factors on the right hand side of the axis at a higher level in medium from loaded samples.
The volcano plots for control-TGF- $\beta 1$ media and control-load media show both similarities and differences between the effects of load and TGF- $\beta 1$ stimulation compared to control conditions. In medium conditioned by both TGF- $\beta 1$ stimulated and loaded scaffolds there was a significant upregulation (found on the right hand side of the Y-axis and above 1.30 on the Y-axis) of BLC, MCP3, MIF, VEGF, MMP13 and PDGFaa compared to control (Fig. 2A\&B). No factors were significantly down regulated in both TGF- $\beta 1$ stimulated and loaded groups compared to controls. Leptin, leptin receptor and MDC were upregulated in medium from TGF- $\beta 1$ stimulated scaffolds 
Table 2. The factors identified by this work as undergoing a significant change in media content in response to load or TGF- $\beta 1$ stimulation and a description of their known links to cartilage/chondrogenesis.

\begin{tabular}{|c|c|c|}
\hline Factor name & Known links to chondrogenesis/cartilage & References \\
\hline Leptin & $\begin{array}{l}\text { Localised to the growth plate and osteoarthritic cartilage. Knock out } \\
\text { mice have disrupted growth plates. Leptin induces GAG loss from } \\
\text { cartilage plugs and activates MMPs. }\end{array}$ & $\begin{array}{l}\text { (Dumond et al., 2003; Hui et al., 2012; Iliopoulos } \\
\text { et al., 2007; Kishida et al., 2005; Kume et al., } \\
\text { 2002; Zeddou et al., 2012) }\end{array}$ \\
\hline Leptin Receptor & $\begin{array}{l}\text { Localised the growth plate and to osteoarthritic cartilage. Expressed by } \\
\text { chondrocytes in monolayer culture. }\end{array}$ & $\begin{array}{l}\text { (Kishida et al., 2005; Ohba et al., 2010; } \\
\text { Simopoulou et al., 2007) }\end{array}$ \\
\hline MDC & Expressed in the synovial tissue of arthritic joints. & (Flytlie et al., 2010) \\
\hline MIP3 $\alpha$ & $\begin{array}{l}\text { Induced MMP13 expression in articular chondrocytes in monolayer } \\
\text { culture. Increased levels found in rheumatic joints. }\end{array}$ & (Lisignoli et al., 2006; Mazzetti et al., 2004) \\
\hline GRO & $\begin{array}{l}\text { Found in arthritic joint and expressed by normal chondrocytes. Capable } \\
\text { of inducing hypertrophy in chondrocytes in vitro. }\end{array}$ & $\begin{array}{l}\text { (Chen et al., 2013a; Merz et al., 2003; Olivotto et } \\
\text { al., 2007; Wenke } \text { et al., 2011) }\end{array}$ \\
\hline uPAR & $\begin{array}{l}\text { Capable of activating MMPs and associated with plasmin, an activator } \\
\text { of TGF- } \beta \text {. }\end{array}$ & $\begin{array}{l}\text { (Beaufort et al., 2004; Blasi and Carmeliet, 2002; } \\
\text { Montuori et al., 2005; Schwab et al., 2004) }\end{array}$ \\
\hline LAP & Released during TGF- $\beta$ activation. & (Maeda et al., 2002) \\
\hline Angiogenin & Found in diseased and arthritic joints. & (Liote et al., 2003) \\
\hline Angiopoietin 2 & Destabilises blood vessel formation by acting as a TIE2 antagonist. & (DeBusk et al., 2003; Horner et al., 2001) \\
\hline Osteoprotegerin & $\begin{array}{l}\text { Found in normal and arthritic cartilage. Chondroprotective in a murine } \\
\text { OA model. }\end{array}$ & (Komuro et al., 2001; Shimizu et al., 2007) \\
\hline DR6 & ( & - \\
\hline TGF- $\beta$ & Induces chondrogenesis in mesenchymal stem cells. & (Johnstone et al., 1998) \\
\hline ALCAM & $\begin{array}{l}\text { Used to identify chondroprogenitor cells. Expressed by chondrocytes } \\
\text { from diseased and normal joints. }\end{array}$ & $\begin{array}{l}\text { (Alsalameh et al., 2004; Arai et al., 2002; Chen et } \\
\text { al., 2013b) }\end{array}$ \\
\hline BLC & $\begin{array}{l}\text { Expressed by chondrogenically differentiated MSCs. BLC } \\
\text { neutralisation reduced the severity within a murine autoimmune } \\
\text { arthritis model. }\end{array}$ & (Cristino et al., 2008; Zheng et al., 2005) \\
\hline MCP3 & - & - \\
\hline MIF & $\begin{array}{l}\text { Detected in RA joints and associated with inflammation and MMP } \\
\text { expression. Neutralisation reduced the severity of a murine autoimmune } \\
\text { arthritis model. }\end{array}$ & (Morand and Leech, 2005; Santos et al., 2001) \\
\hline VEGF & $\begin{array}{l}\text { Expressed by normal and hypertrophic chondrocytes. Important in } \\
\text { hypertrophy, chondrocyte specific inactivation leads to failed endo- } \\
\text { chondral ossification. }\end{array}$ & (Bluteau et al., 2007; Dai and Rabie, 2007) \\
\hline MMP13 & $\begin{array}{l}\text { Involved in cartilage turnover and acts as a marker of MSC and chon- } \\
\text { drocyte hypertrophy. }\end{array}$ & (Mueller and Tuan, 2008) \\
\hline PDGF & Important in chondrogenesis during development. & (Ataliotis, 2000) \\
\hline
\end{tabular}

compared to controls but did not change in medium from loaded scaffolds compared to controls. MIP $3 \alpha$, uPAR, LAP and angiogenin were detected at significantly levels in response to load compared to control, but did not change in TGF- $\beta 1$ compared to controls, whilst the concentration of GRO was significantly lower in response to load but did not change significantly in response to TGF- $\beta 1$ stimulation.

The third volcano plot (Fig. 2C) shows the results of a direct comparison between media from TGF- $\beta 1$ stimulated scaffolds and loaded scaffolds. In this plot, factors detected at a higher level in media collected from loaded scaffolds are found on the left hand side of the Y-axis and factors found at a higher level in media from TGF- $\beta 1$ stimulated scaffolds are found on the right hand side of the Y-axis. This plot clearly shows that the majority of factors measured were found at a higher level in the media collected from loaded scaffolds. Angiopoietin 2, osteoprotegerin, ALCAM and DR6 were found at higher levels in loaded media than TGF- $\beta 1$ stimulated media whilst TGF- $\beta 1$ was found at higher levels in TGF- $\beta 1$ stimulated medium than loaded medium.

The comparisons made between the three groups have been provided in the form of box plots (Fig. 3) as well as in the volcano plots (Fig. 2) in order to display the results in a factor by factor manner. Six factors (BLC,
MCP3, MIF, VEGF, MMP13 and PDGFaa) were found to change significantly in both TGF- $\beta 1$ and loaded groups compared to controls. In all of these cases the factors were significantly higher in TGF- $\beta 1$ and loaded groups than controls (Table 1, Fig. 3D, J, L, N, $\mathbf{P}$ and $\mathbf{Q}$ ). The similarities in the responses of these factors indicate similarities in the effects of these two forms of stimulation, potentially due to the effect of TGF- $\beta 1$ signalling in both systems.

ALCAM was significantly increased in the loaded group over both control and TGF- $\beta 1$ stimulated groups showing a clear difference in effect between load and TGF- $\beta 1$ stimulation (Table 1, Fig. 3A).

Table 2 provides information on the interactions that are described in the literature between the factors that changed significantly in this study with/on cartilage/chondrogenesis.

\section{Real-time PCR gene expression analysis}

Real-time PCR was performed in order to determine the relative gene expression levels of factors that demonstrated significant changes between groups in the secretome analysis. Of the 19 factors that underwent significant changes, 9 were chosen for real-time PCR analysis based on their expression as soluble and not membrane bound proteins, and evidence for a potential link to 
A.

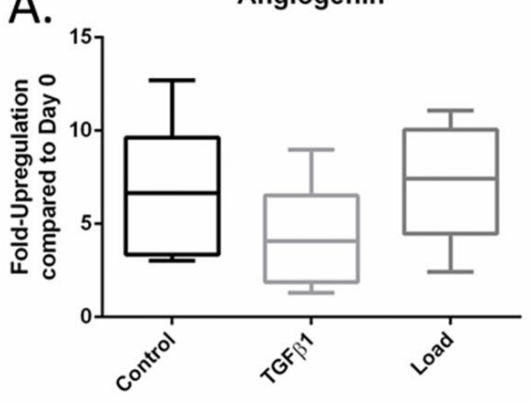

D.



G.

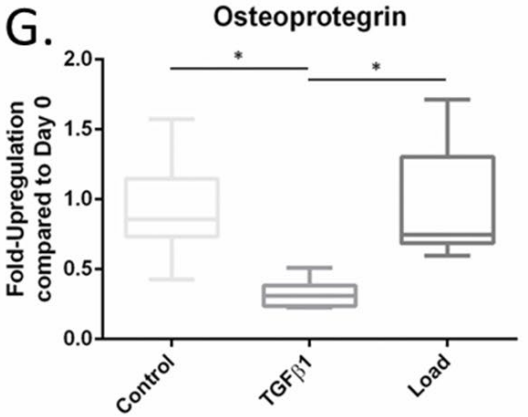

B.

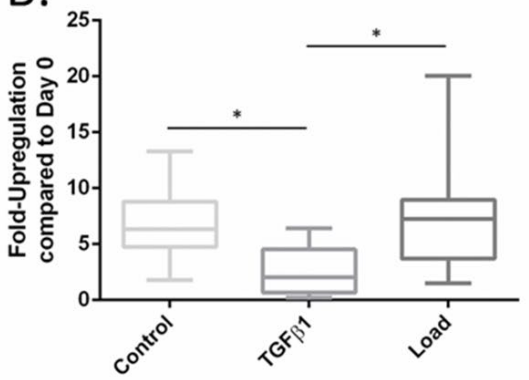

E.

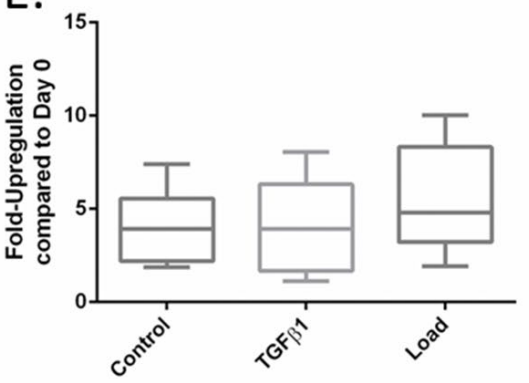

$\mathrm{H}$.

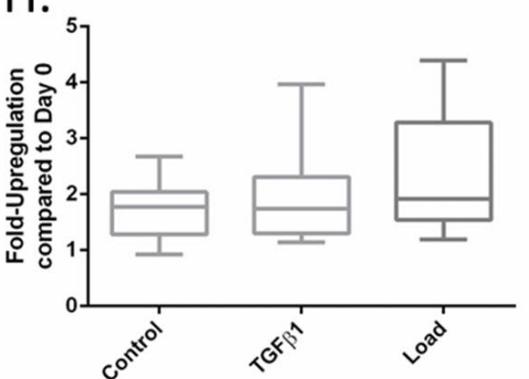

C.

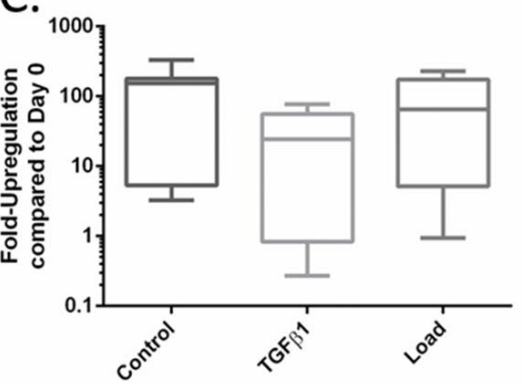

F.

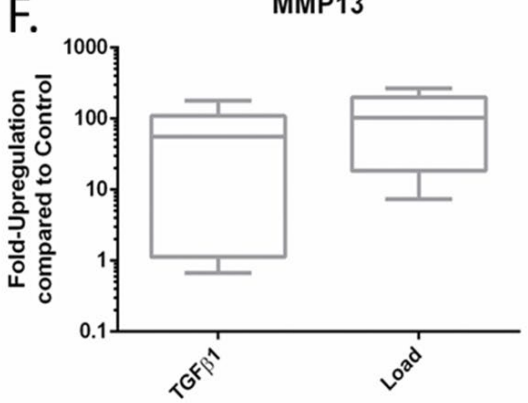

I.



Fig. 4. Box plots showing the results of real-time PCR. This figure contains shows the results of the 12 factors investigated, each of which had showed a significant change between in at least one comparison made between groups during secretome analysis (the three comparisons were between control and TGF- $\beta 1$, between load and controls and load and TGF- $\beta 1$ ). Statistical significance was defined as $p \leq 0.05$ and determined using the Kurskal-Wallis and Dunn's multiple comparison tests. * represents $p \leq 0.05, * *$ represents $p \leq 0.001$ and $* * *$ represents $p \leq 0.0001$.

chondrogenesis, hypertrophy or mechanical load in the literature. Membrane bound proteins were not analysed as changes in receptor turnover and shedding mean that comparison between media protein levels and mRNA levels difficult to reconcile. The factors were; angiogenin, angiopoietin 2, GRO $\alpha$, leptin, MIF, MMP13, OPG, PDGFa and VEGF.

Results of real-time PCR for angiopoietin 2 and osteoprotegerin show that as in the secretome analysis the expression in the TGF- $\beta 1$ group is significantly lower than in the loaded group, in the PCR analysis the expression level is also seen to be lower in the TGF- $\beta 1$ stimulated group than in control scaffolds (Fig. 4B and $\mathbf{G}$ ). The expression of MMP13 was normalised to the control group as the expression of MMP13 in cells at day 0 was donor dependent. Real-time PCR shows that the expression of MMP13 is similar in TGF- $\beta 1$ stimulated and loaded groups and that also the expression in both groups is much higher than control groups (Fig. 4F). The expression of GRO was also lower than controls in both stimulated groups
(Fig. 4C), although not as strongly as suggested by the secretome data or other results collected by this group (data not shown).

Secretome analysis showed that leptin was detected at a higher level in media from TGF- $\beta 1$ stimulated scaffolds than control samples, whilst angiogenin was detected at a higher level in loaded samples than controls (Fig. 3B and $\mathbf{H}$ ). For both of these factors real-time PCR analysis showed no difference between stimulated groups in the case of leptin (which as with MMP13 was normalised to the control groups due to donor dependent expression at day 0 ) or stimulated groups and controls in the case of angiogenin (Fig. 4A and D).

The results of secretome analysis showed that MIF, PDGFaa and VEGF were all detected at higher levels in both TGF- $\beta 1$ stimulated and loaded groups than controls, whilst not being significantly different from each other (Fig. $3 \mathbf{L}, \mathbf{P}$ and $\mathbf{Q}$ ). This was not reflected in gene expression analysis where neither stimulated group was found to be significantly different from controls (Fig. 4E, H and I). 
Fig. 5. Quantification of nitrite (as an indirect marker measure of nitric oxide (NO)) in the culture media of control, TGF- $\beta 1$ stimulated and loaded scaffolds by week, over four weeks of culture. Statistical significance was defined as $p \leq 0.05$ and determined using the Kurskal-Wallis and Dunn's multiple comparison tests. * represents $p \leq 0.05$,** represents $p \leq 0.001$ and $* * *$ represents $p \leq 0.0001$.


\section{Media nitrite quantification}

A number of the factors identified by the initial secretome analysis are known to respond to shear forces in other model systems (angiopoietin-2, PDGF and MCP3). Another factor commonly associated with shear loading, particularly in vascular cells, is nitric oxide. In order to investigate the effect of load on nitric oxide in this system, the presence of inorganic nitrite was detected in the culture media using the Griess reaction. Results showed that at all four time points (day two, four, six and eight) the level of nitrites detected in the TGF- $\beta 1$ stimulated group was significantly lower than that of the loaded group, but not significantly different from the control group (Fig. 5A, B, $\mathbf{C}$ and D). There were significantly higher levels of nitrites in the culture media of loaded scaffolds compared to both control and TGF- $\beta 1$ stimulated scaffolds on days four, six and eight (Fig. 5A, B, C and D). No significant difference was detected between loaded scaffolds and controls on day 2 (Fig. 5A).

\section{Discussion}

Currently accepted methods for the induction of chondrogenesis in MSCs use a combination of 3D culture and the exogenous administration of an active recombinant isoform of TGF- $\beta$ (Barry et al., 2001; Johnstone et al., 1998). Recent work has shown that chondrogenesis can be induced in MSCs using multiaxial mechanical load in the absence of exogenous TGF- $\beta$ (Li et al., 2010a; Li et al., 2010b; Schatti et al., 2011). The purpose of this investigation was to compare the secretomes MSCs stimulated either with exogenous TGF- $\beta$ or multiaxial load with each other and with unstimulated control scaffolds, to highlight similarities and differences between these two forms of chondrogenic induction and determine interesting or potentially novel factors for MSC based cartilage tissue engineering.

BLC, MCP3, MIF, VEGF, MMP13 and PDGF were upregulated in response to both load and TGF- $\beta 1$ stimulation and may represent a core of factors that are responsive to TGF- $\beta 1$, which is known to be involved in the induction of chondrogenesis in the loaded scaffolds as well as the TGF- $\beta 1$ stimulated scaffolds (Li et al., 2010a). MMP13 is a well characterised and described marker associated with chondrocyte and MSC hypertrophy (D'Angelo et al., 2000). The secretion of BLC in to the culture media has previously been described on day seven of the TGF- $\beta$ driven chondrogenesis of MSCs. However, little information is available to suggest a role for BLC in MSC chondrogenesis (Cristino et al., 2008). MCP3 has been shown to be induced by TGF- $\beta$ in fibroblasts in a SMAD dependent manner and in response to mechanical stimulation in osteocytes (Ong et al., 2009). The production of both PDGFaa and VEGF is known to be responsive to TGF- $\beta$ (Jeon et al., 2007; Tanabe et al., 2006; Wang et al., 1997). These factors therefore have clear links to TGF- $\beta 1$ or TGF- $\beta 1$ driven chondrogenesis and this may explain the similarities between loaded and TGF- $\beta 1$ stimulated scaffolds when compared to control scaffolds. The expression of all six of these factors has also previously been described in MSCs (Cristino et al., 2008; Grassel et al., 2009; Hoch et al., 2012; Kinnaird et al., 2004; Palumbo et al., 2014; Rehman et al., 2004; Ribeiro et al., 2012; Sze et al., 2007). Some of these factors have also previously been associated with similar responses to TGF- $\beta$ in a 
range of cell types e.g. BLC, MCP3, VEGF, MMP13 and PDGFaa (Cristino et al., 2008; Fitzgerald et al., 2008; Jeon et al., 2007; Ong et al., 2009; Tanabe et al., 2006; Wang et al., 1997).

As well as factors that responded similarly to both forms of chondrogenic induction there were a number that underwent different responses. Leptin has been localised to the synovial fluid of arthritic joints and is found at a higher level in cartilage from arthritic joints than normal cartilage (Kume et al., 2002). A role for leptin has also been suggested in the growth plate where leptin knock out leads to disrupted column formation and reduced collagen type $\mathrm{X}$ production (Kishida et al., 2005). These observations in vivo suggest that leptin is involved in hypertrophy and may act as a marker of hypertrophy. This is supported by work by Iliopoulos et al. (2007), who showed that leptin could stimulate MMP13 expression in articular chondrocytes in vitro and that siRNA knock down of leptin expression leads to a reduction in MMP13 production. This suggests that the increase in leptin, in response to TGF- $\beta$ stimulation, may be indicative of a more hypertrophic phenotype than that induced by load. However, further work would be required to investigate this. Should leptin's hypertrophic effects on MSCs be verified then it would provide and interesting avenue for reducing hypertrophy within cartilage tissue engineering.

Little is known regarding the role of or effect on chondrogenesis of MDC. However, its expression has been detected in the synovial tissue of patients with rheumatic and psoriatic arthritis. The presence of MDC in these tissues may be due to its role in inflammation and further work is required to determine its effect of chondrogenesis (Flytlie et al., 2010).

LAP is released from the mature TGF- $\beta 1$ peptide during activation. Mechanical loading and, in particular, shear loading has been shown to activate TGF- $\beta$, an effect also seen within the bioreactor culture system presented in this paper (Paper in review) (Ahamed et al., 2008; Albro et al., 2012; Annes et al., 2004; Wipff et al., 2007). The increased presence of LAP in the culture media of loaded scaffolds is, therefore, likely to be due to activation of endogenously produced pro-forms of TGF- $\beta$.

The expression of GRO has been detected in osteoarthritic chondrocytes, and has is capable of inducing the expression hypertrophic markers such as MMP13 and collagen type $\mathrm{X}$, as well as mineralisation in chondrocytes (Endres et al., 2010; Merz et al., 2003; Olivotto et al., 2007). These results suggest that the reduction in GRO expression in response to TGF- $\beta 1$ stimulation and mechanical load expression marks an anti-hypertrophic effect. This may be an interesting avenue for cartilage repair. Hypertrophy is a major bar on the use of MSCs clinically and targeting factors such as GRO that are involved in hypertrophy may provide ways of circumventing this issue.

Both angiopoietin-2 and osteoprotegerin have been shown to be induced by the application of shear forces which may be linked to their increased presence in media from loaded scaffolds over TGF- $\beta 1$ stimulated scaffolds (Goettsch et al., 2008; Kim et al., 2006; Li et al., 2014).

The amount of TGF- $\beta 1$ detected in the culture media by cytokine array was significantly higher at day eight in TGF- $\beta 1$ stimulated samples than both control and loaded samples. This is at odds with the result of the ELISA quantification of day eight media, which showed that there was no significant difference in the media TGF- $\beta 1$ concentration of loaded and TGF- $\beta 1$ stimulated groups. The ELISA data also indicated that both TGF- $\beta 1$ stimulated groups and loaded groups were significantly higher than the control group on day eight. However, the results of the cytokine array also demonstrated that the overall fold change between TGF- $\beta 1$ and load was 1.17 and between TGF- $\beta 1$ and control 1.2, suggesting very little overall difference the total amounts of TGF- $\beta 1$ present. These changes are lower than the 1.5-fold change used by Rodriguez et al. to denote significance and the 2-fold change used to class a factor as physiologically relevant by Grassel et al. (Grassel et al., 2009; Rodriguez et al., 2015). This result highlights the fact that this form of analysis is extremely valuable for identifying the presence of potential factors of interest within samples. But, more precise techniques incorporating standard curves, such as ELISA, should be performed for absolute quantification.

Following the results of secretome analysis, this work was repeated to confirm that the changes seen at a protein level were also detectable at a gene expression level using real-time PCR. The results of real-time PCR analysis confirmed some of the changes seen in the secretome data e.g. for angiopoietin 2 and osteoprotegerin, but did not support the changes seen in all the factors e.g. VEGF and PDGFa. The detection of similar changes in secretome analysis and gene expression suggests that the changes seen in these factors are robust; this highlights angiopoietin 2, osteoprotegerin, MMP13 and GROa as factors of particular interest. The difference in the gene expression and protein analysis for these genes may relate to the time points of sample collection. The media used for the secretome analysis were conditioned between days 6 and 8 of culture, whilst the mRNA collection represents a single time point on day 8. As a result, the gene expression profiles of these factors may have risen and fallen again before the sampling on day 8 , and may explain the difference in mRNA and protein profiles. Alternatively, this may be due to the small fold changes seen in the secretome results for these factors, which may explain the lack of a significant change in gene expression levels despite a statistically significant change in the amounts of protein detected.

Study of the literature associated with the factors identified during the secretome analysis highlighted similar responses to shear force with regards to factors such as angiopoietin-2, PDGF and MCP3 in other cell types and model systems. The literature also highlighted the increase in nitric oxide (NO) production in response to shear loading in endothelial cells in response to mechanical shear forces (Bao et al., 1999; Goettsch et al., 2008). In MSCs, NO production has previously been shown to be induced in response to fluid flow induced shear loading (Knippenberg et al., 2005), and also has been shown to play a role in MSC immunomodulation through the suppression of the T-cell response (Ren et al., 2008; Sato et al., 2007). The clear changes in NO production in response to joint-like multiaxial load suggest that NO production mechanisms could be targeted for therapeutic benefit. This work is 
the first to implicate NO as a potential influencing factor during the multiaxial load applied after marrow stimulation techniques (which result in the formation of a fibrin clot containing MSCs). NO has been widely linked to arthritis, particularly the upregulation of MMPs, matrix degradation and the suppression of proteoglycan and collagen synthesis (Abramson, 2008). Nitric oxide also has a negative effect on TGF- $\beta$ expression which has leads to a reduction in GAG production as a result in the reduction of TGF- $\beta$ (Studer et al., 1999). Previous work in to this area has shown that the suppression of nitric oxide synthase (NOS) can reduce the severity of symptoms in a murine model of arthritis (McCartney-Francis et al., 1993). Therefore, reducing the local presence of NO in joints during post-operative rehabilitation e.g. after microfracture, could improve the outcome of cartilage repair by reducing the effects of NO on cartilage matrix synthesis, cartilage degradation and TGF- $\beta$ signalling. However, further work is required to identify the role of NO in response to load and the effect that it has on MSC chondrogenesis, as NO may play a direct role in mechanotransduction and, therefore, the generation of cartilage-like repair material in response to joint loading in vitro. A clear next step is to establish whether the NO plays a role in mechanotransduction, and whether it has an inhibitory effect on cartilage tissue development under these conditions and the extent to which NO levels can be modulated to improve chondrogenic outcomes.

\section{Conclusions}

The results of secretome analysis presented here show that there are clear similarities and differences between the secretomes of MSCs stimulated with multiaxial mechanical load or TGF- $\beta 1$. Nineteen factors were identified by secretome analysis as being significantly different in two or more groups. Of particular interest are the four factors (angiopoietin 2, GRO $\alpha, \mathrm{MMP} 13$ and osteoprotegerin) whose changes in secretome profile between the groups were mirrored by their changes in gene expression as determined by real-time PCR. Alongside these factors, this work identifies for the first time an increase in NO production in response to joint stimulating mechanical load. These data demonstrate that the chondrogenic effects of multiaxial mechanical load and stimulation with exogenous TGF- $\beta 1$ are not analogous. The factors identified by this work, and their potential for manipulation, presents a multitude of novel and interesting avenues for further investigation with regards to mesenchymal stem cells and cartilage tissue engineering.

\section{Acknowledgements}

This work was supported by the Acute Cartilage Injury consortium of the AO Foundation and the Swiss National Science Foundation (Grant no: 31003a_146375/1). We would like to M. Glarner and Dr. David Eglin (Musculoskeletal Regeneration Program, AO Foundation Research Institute, Davos) for producing the polyurethane scaffolds and Baxter Biosurgery, Vienna, for providing the fibrin components.

\section{References}

Abramson SB (2008) Osteoarthritis and nitric oxide. Osteoarthritis Cartilage 16 Suppl 2: S15-20.

Ahamed J, Burg N, Yoshinaga K, Janczak CA, Rifkin $\mathrm{DB}$, Coller BS (2008) In vitro and in vivo evidence for shear-induced activation of latent transforming growth factor-beta1. Blood 112: 3650-3660.

Albro MB, Cigan AD, Nims RJ, Yeroushalmi KJ, Oungoulian SR, Hung CT, Ateshian GA (2012) Shearing of synovial fluid activates latent TGF-beta. Osteoarthritis Cartilage 20: 1374-1382.

Alsalameh S, Amin R, Gemba T, Lotz M (2004) Identification of mesenchymal progenitor cells in normal and osteoarthritic human articular cartilage. Arthritis Rheum 50: 1522-1532.

Annes JP, Chen Y, Munger JS, Rifkin DB (2004) Integrin alphaVbeta6-mediated activation of latent TGFbeta requires the latent TGF-beta binding protein-1. J Cell Biol 165: 723-734.

Arai F, Ohneda O, Miyamoto T, Zhang XQ, Suda T (2002) Mesenchymal stem cells in perichondrium express activated leukocyte cell adhesion molecule and participate in bone marrow formation. J Exp Med 195: 1549-1563.

Arufe MC, De la Fuente A, Mateos J, Fuentes I, De Toro FJ, Blanco FJ (2011) Analysis of the chondrogenic potential and secretome of mesenchymal stem cells derived from human umbilical cord stroma. Stem Cells Dev 20: 1199-1212.

Ataliotis P (2000) Platelet-derived growth factor A modulates limb chondrogenesis both in vivo and in vitro. Mech Dev 94: 13-24.

Bao X, Lu C, Frangos JA (1999) Temporal gradient in shear but not steady shear stress induces PDGF-A and MCP-1 expression in endothelial cells: role of $\mathrm{NO}, \mathrm{NF}$ kappa B, and egr-1. Arterioscler Thromb Vasc Biol 19: 996-1003.

Bara JJ, McCarthy HE, Humphrey E, Johnson WE, Roberts S (2014) Bone marrow-derived mesenchymal stem cells become antiangiogenic when chondrogenically or osteogenically differentiated: implications for bone and cartilage tissue engineering. Tissue Eng Part A 20: 147-159.

Barry F, Boynton RE, Liu B, Murphy JM (2001) Chondrogenic differentiation of mesenchymal stem cells from bone marrow: differentiation-dependent gene expression of matrix components. Exp Cell Res 268: 189200.

Beaufort N, Leduc D, Rousselle JC, Magdolen V, Luther T, Namane A, Chignard M, Pidard D (2004) Proteolytic regulation of the urokinase receptor/CD87 on monocytic cells by neutrophil elastase and cathepsin G. J Immunol 172: 540-549.

Blasi F, Carmeliet P (2002) uPAR: a versatile signalling orchestrator. Nat Rev Mol Cell Biol 3: 932-943.

Bluteau G, Julien M, Magne D, Mallein-Gerin F, Weiss P, Daculsi G, Guicheux J (2007) VEGF and VEGF 
receptors are differentially expressed in chondrocytes. Bone 40: 568-576.

Caplan AI (2007) Adult mesenchymal stem cells for tissue engineering versus regenerative medicine. J Cell Physiol 213: 341-347.

Chen HW, Chen HY, Wang LT, Wang FH, Fang LW, Lai HY, Chen HH, Lu J, Hung MS, Cheng Y, Chen MY, Liu SJ, Chong P, Lee OK, Hsu SC (2013a) Mesenchymal stem cells tune the development of monocyte-derived dendritic cells toward a myeloid-derived suppressive phenotype through growth-regulated oncogene chemokines. J Immunol 190: 5065-5077.

Chen W, Tang Y, Zheng M, Jiang J, Zhu G, Liang X, Li M (2013b) Regulation of plasminogen activator activity and expression by cyclic mechanical stress in rat mandibular condylar chondrocytes. Mol Med Rep 8: 1155 1162.

Cristino S, Piacentini A, Manferdini C, Codeluppi K, Grassi F, Facchini A, Lisignoli G (2008) Expression of CXC chemokines and their receptors is modulated during chondrogenic differentiation of human mesenchymal stem cells grown in three-dimensional scaffold: evidence in native cartilage. Tissue Eng Part A 14: 97-105.

Czekanska EM, Ralphs JR, Alini M, Stoddart MJ (2014) Enhancing inflammatory and chemotactic signals to regulate bone regeneration. Eur Cell Mater 28: 320-334.

D’Angelo M, Billings PC, Pacifici M, Leboy PS, Kirsch T (2001) Authentic matrix vesicles contain active metalloproteases (MMP). a role for matrix vesicleassociated MMP-13 in activation of transforming growth factor-beta. J Biol Chem 276: 11347-11353.

D’Angelo M, Yan Z, Nooreyazdan M, Pacifici M, Sarment DS, Billings PC, Leboy PS (2000) MMP-13 is induced during chondrocyte hypertrophy. J Cell Biochem 77: 678-693.

Dai J, Rabie AB (2007) VEGF: an essential mediator of both angiogenesis and endochondral ossification. J Dent Res 86: 937-950.

De Lisio M, Jensen T, Sukiennik RA, Huntsman HD, Boppart MD (2014) Substrate and strain alter the musclederived mesenchymal stem cell secretome to promote myogenesis. Stem Cell Res Ther 5: 74.

DeBusk LM, Chen Y, Nishishita T, Chen J, Thomas JW, Lin PC (2003) Tie2 receptor tyrosine kinase, a major mediator of tumor necrosis factor alpha-induced angiogenesis in rheumatoid arthritis. Arthritis Rheum 48: 2461-2471.

Dumond H, Presle N, Terlain B, Mainard D, Loeuille D, Netter P, Pottie P (2003) Evidence for a key role of leptin in osteoarthritis. Arthritis Rheum 48: 3118-3129.

Endres M, Andreas K, Kalwitz G, Freymann U, Neumann K, Ringe J, Sittinger M, Haupl T, Kaps C (2010) Chemokine profile of synovial fluid from normal, osteoarthritis and rheumatoid arthritis patients: CCL25, CXCL10 and XCL1 recruit human subchondral mesenchymal progenitor cells. Osteoarthritis Cartilage 18: 1458-1466.

Fitzgerald JB, Jin M, Chai DH, Siparsky P, Fanning P, Grodzinsky AJ (2008) Shear- and compression-induced chondrocyte transcription requires MAPK activation in cartilage explants. J Biol Chem 283: 6735-6743.
Flytlie HA, Hvid M, Lindgreen E, Kofod-Olsen E, Petersen EL, Jorgensen A, Deleuran M, Vestergaard C, Deleuran B (2010) Expression of MDC/CCL22 and its receptor CCR4 in rheumatoid arthritis, psoriatic arthritis and osteoarthritis. Cytokine 49: 24-29.

Furumatsu T, Tsuda M, Taniguchi N, Tajima Y, Asahara $\mathrm{H}$ (2005) Smad3 induces chondrogenesis through the activation of SOX9 via CREB-binding protein/p300 recruitment. J Biol Chem 280: 8343-8350.

Goettsch W, Gryczka C, Korff T, Ernst E, Goettsch C, Seebach J, Schnittler HJ, Augustin HG, Morawietz H (2008) Flow-dependent regulation of angiopoietin-2. J Cell Physiol 214: 491-503.

Goldring MB, Tsuchimochi K, Ijiri K (2006) The control of chondrogenesis. J Cell Biochem 97: 33-44.

Grad S, Lee CR, Gorna K, Gogolewski S, Wimmer MA, Alini M (2005) Surface motion upregulates superficial zone protein and hyaluronan production in chondrocyte-seeded three-dimensional scaffolds. Tissue Eng 11: 249-256.

Grassel S, Ahmed N, Gottl C, Grifka J (2009) Gene and protein expression profile of naive and osteochondrogenically differentiated rat bone marrow-derived mesenchymal progenitor cells. Int J Mol Med 23: 745-755.

Haynesworth SE, Baber MA, Caplan AI (1996) Cytokine expression by human marrow-derived mesenchymal progenitor cells in vitro: effects of dexamethasone and IL-1 alpha. J Cell Physiol 166: 585-592.

Hellingman CA, Davidson EN, Koevoet W, Vitters EL, van den Berg WB, van Osch GJ, van der Kraan PM (2011) Smad signaling determines chondrogenic differentiation of bone-marrow-derived mesenchymal stem cells: inhibition of Smad1/5/8P prevents terminal differentiation and calcification. Tissue Eng Part A 17: 1157-1167.

Hoch AI, Binder BY, Genetos DC, Leach JK (2012) Differentiation-dependent secretion of proangiogenic factors by mesenchymal stem cells. PLoS One 7: e35579.

Horner A, Bord S, Kelsall AW, Coleman N, Compston JE (2001) Tie2 ligands angiopoietin-1 and angiopoietin-2 are coexpressed with vascular endothelial cell growth factor in growing human bone. Bone 28: 65-71.

Hui W, Litherland GJ, Elias MS, Kitson GI, Cawston TE, Rowan AD, Young DA (2012) Leptin produced by joint white adipose tissue induces cartilage degradation via upregulation and activation of matrix metalloproteinases. Ann Rheum Dis 71: 455-462.

Iliopoulos D, Malizos KN, Tsezou A (2007) Epigenetic regulation of leptin affects MMP-13 expression in osteoarthritic chondrocytes: possible molecular target for osteoarthritis therapeutic intervention. Ann Rheum Dis 66: 1616-1621.

Jeon SH, Chae BC, Kim HA, Seo GY, Seo DW, Chun GT, Kim NS, Yie SW, Byeon WH, Eom SH, Ha KS, Kim YM, Kim PH (2007) Mechanisms underlying TGFbeta1-induced expression of VEGF and Flk-1 in mouse macrophages and their implications for angiogenesis. $\mathrm{J}$ Leukoc Biol 81: 557-566.

Johansson N, Saarialho-Kere U, Airola K, Herva R, Nissinen L, Westermarck J, Vuorio E, Heino J, Kahari VM (1997) Collagenase-3 (MMP-13) is expressed by hypertrophic chondrocytes, periosteal cells, and osteoblasts 
during human fetal bone development. Dev Dyn 208: $387-$ 397.

Johnstone B, Hering TM, Caplan AI, Goldberg VM, Yoo JU (1998) In vitro chondrogenesis of bone marrowderived mesenchymal progenitor cells. Exp Cell Res 238: 265-272.

Kim CH, You L, Yellowley CE, Jacobs CR (2006) Oscillatory fluid flow-induced shear stress decreases osteoclastogenesis through RANKL and OPG signaling. Bone 39: 1043-1047.

Kinnaird T, Stabile E, Burnett MS, Lee CW, Barr S, Fuchs S, Epstein SE (2004) Marrow-derived stromal cells express genes encoding a broad spectrum of arteriogenic cytokines and promote in vitro and in vivo arteriogenesis through paracrine mechanisms. Circ Res 94: 678-685.

Kishida Y, Hirao M, Tamai N, Nampei A, Fujimoto T, Nakase T, Shimizu N, Yoshikawa H, Myoui A (2005) Leptin regulates chondrocyte differentiation and matrix maturation during endochondral ossification. Bone 37: 607-621.

Knippenberg M, Helder MN, Doulabi BZ, Semeins CM, Wuisman PI, Klein-Nulend J (2005) Adipose tissue-derived mesenchymal stem cells acquire bone celllike responsiveness to fluid shear stress on osteogenic stimulation. Tissue Eng 11: 1780-1788.

Komuro H, Olee T, Kuhn K, Quach J, Brinson DC, Shikhman A, Valbracht J, Creighton-Achermann L, Lotz M (2001) The osteoprotegerin/receptor activator of nuclear factor kappaB/receptor activator of nuclear factor kappaB ligand system in cartilage. Arthritis Rheum 44: 2768-2776.

Kume K, Satomura K, Nishisho S, Kitaoka E, Yamanouchi K, Tobiume S, Nagayama M (2002) Potential role of leptin in endochondral ossification. J Histochem Cytochem 50: 159-169.

Kupcsik L, Alini M, Stoddart MJ (2009) Epsilonaminocaproic acid is a useful fibrin degradation inhibitor for cartilage tissue engineering. Tissue Eng Part A 15: 2309-2313.

Li R, Beebe T, Jen N, Yu F, Takabe W, Harrison M, Cao H, Lee J, Yang H, Han P, Wang K, Shimizu H, Chen J, Lien CL, Chi NC, Hsiai TK (2014) Shear stress-activated Wnt-angiopoietin-2 signaling recapitulates vascular repair in zebrafish embryos. Arterioscler Thromb Vasc Biol 34: 2268-2275.

Li Z, Kupcsik L, Yao SJ, Alini M, Stoddart MJ (2009) Chondrogenesis of human bone marrow mesenchymal stem cells in fibrin-polyurethane composites. Tissue Eng Part A 15: 1729-1737.

Li Z, Kupcsik L, Yao SJ, Alini M, Stoddart MJ (2010a) Mechanical load modulates chondrogenesis of human mesenchymal stem cells through the TGF-beta pathway. J Cell Mol Med 14: 1338-1346.

Li Z, Yao SJ, Alini M, Stoddart MJ (2010b) Chondrogenesis of human bone marrow mesenchymal stem cells in fibrin-polyurethane composites is modulated by frequency and amplitude of dynamic compression and shear stress. Tissue Eng Part A 16: 575-584.

Liote F, Champy R, Moenner M, Boval-Boizard B, Badet J (2003) Elevated angiogenin levels in synovial fluid from patients with inflammatory arthritis and secretion of angiogenin by cultured synovial fibroblasts. Clin Exp Immunol 132: 163-168.

Lisignoli G, Toneguzzi S, Piacentini A, Cristino S, Grassi F, Cavallo C, Facchini A (2006) CXCL12 (SDF-1) and CXCL13 (BCA-1) chemokines significantly induce proliferation and collagen type I expression in osteoblasts from osteoarthritis patients. J Cell Physiol 206: 78-85.

Liu CH, Hwang SM (2005) Cytokine interactions in mesenchymal stem cells from cord blood. Cytokine 32: 270-279.

Mackie EJ, Tatarczuch L, Mirams M (2011) The skeleton: a multi-functional complex organ: the growth plate chondrocyte and endochondral ossification. J Endocrinol 211: 109-121.

Maeda S, Dean DD, Gomez R, Schwartz Z, Boyan BD (2002) The first stage of transforming growth factor beta1 activation is release of the large latent complex from the extracellular matrix of growth plate chondrocytes by matrix vesicle stromelysin-1 (MMP-3). Calcif Tissue Int 70: $54-65$.

Mazzetti I, Magagnoli G, Paoletti S, Uguccioni M, Olivotto E, Vitellozzi R, Cattini L, Facchini A, Borzi RM (2004) A role for chemokines in the induction of chondrocyte phenotype modulation. Arthritis Rheum 50: 112-122.

McCartney-Francis N, Allen JB, Mizel DE, Albina JE, Xie QW, Nathan CF, Wahl SM (1993) Suppression of arthritis by an inhibitor of nitric oxide synthase. J Exp Med 178: 749-754.

Merz D, Liu R, Johnson K, Terkeltaub R (2003) IL-8/ CXCL8 and growth-related oncogene alpha/CXCL1 induce chondrocyte hypertrophic differentiation. J Immunol 171: 4406-4415.

Montuori N, Visconte V, Rossi G, Ragno P (2005) Soluble and cleaved forms of the urokinase-receptor: degradation products or active molecules? Thromb Haemost 93: 192-198.

Morand EF, Leech M (2005) Macrophage migration inhibitory factor in rheumatoid arthritis. Front Biosci 10: 12-22.

Mueller MB, Tuan RS (2008) Functional characterization of hypertrophy in chondrogenesis of human mesenchymal stem cells. Arthritis Rheum 58: 1377-1388.

Ohba S, Lanigan TM, Roessler BJ (2010) Leptin receptor JAK2/STAT3 signaling modulates expression of Frizzled receptors in articular chondrocytes. Osteoarthritis Cartilage 18: 1620-1629.

Olivotto E, Vitellozzi R, Fernandez P, Falcieri E, Battistelli M, Burattini S, Facchini A, Flamigni F, Santi S, Facchini A, Borzi RM (2007) Chondrocyte hypertrophy and apoptosis induced by GROalpha require threedimensional interaction with the extracellular matrix and a co-receptor role of chondroitin sulfate and are associated with the mitochondrial splicing variant of cathepsin B. J Cell Physiol 210: 417-427.

Ong VH, Carulli MT, Xu S, Khan K, Lindahl G, Abraham DJ, Denton CP (2009) Cross-talk between MCP3 and TGFbeta promotes fibroblast collagen biosynthesis. Exp Cell Res 315: 151-161.

Oskowitz A, McFerrin H, Gutschow M, Carter ML, Pochampally R (2011) Serum-deprived human multipotent 
mesenchymal stromal cells (MSCs) are highly angiogenic. Stem Cell Res 6: 215-225.

Palumbo S, Tsai TL, Li WJ (2014) Macrophage migration inhibitory factor regulates AKT signaling in hypoxic culture to modulate senescence of human mesenchymal stem cells. Stem Cells Dev 23: 852-865.

Rehman J, Traktuev D, Li J, Merfeld-Clauss S, Temm-Grove CJ, Bovenkerk JE, Pell CL, Johnstone BH, Considine RV, March KL (2004) Secretion of angiogenic and antiapoptotic factors by human adipose stromal cells. Circulation 109: 1292-1298.

Ren G, Zhang L, Zhao X, Xu G, Zhang Y, Roberts AI, Zhao RC, Shi Y (2008) Mesenchymal stem cell-mediated immunosuppression occurs via concerted action of chemokines and nitric oxide. Cell Stem Cell 2: 141-150.

Ribeiro CA, Fraga JS, Graos M, Neves NM, Reis RL, Gimble JM, Sousa N, Salgado AJ (2012) The secretome of stem cells isolated from the adipose tissue and Wharton jelly acts differently on central nervous system derived cell populations. Stem Cell Res Ther 3: 18.

Rocha B, Calamia V, Casas V, Carrascal M, Blanco FJ, Ruiz-Romero C (2014) Secretome analysis of human mesenchymal stem cells undergoing chondrogenic differentiation. J Proteome Res 13: 1045-1054.

Rodriguez TM, Saldias A, Irigo M, Zamora JV, Perone MJ, Dewey RA (2015) Effect of TGF-beta1 Stimulation on the Secretome of Human Adipose-Derived Mesenchymal Stromal Cells. Stem Cells Transl Med 4: 894-898.

Santos L, Hall P, Metz C, Bucala R, Morand EF (2001) Role of macrophage migration inhibitory factor (MIF) in murine antigen-induced arthritis: interaction with glucocorticoids. Clin Exp Immunol 123: 309-314.

Sato K, Ozaki K, Oh I, Meguro A, Hatanaka K, Nagai T, Muroi K, Ozawa K (2007) Nitric oxide plays a critical role in suppression of T-cell proliferation by mesenchymal stem cells. Blood 109: 228-234.

Schatti O, Grad S, Goldhahn J, Salzmann G, Li Z, Alini M, Stoddart MJ (2011) A combination of shear and dynamic compression leads to mechanically induced chondrogenesis of human mesenchymal stem cells. Eur Cell Mater 22: 214-225.

Schwab W, Schulze-Tanzil G, Mobasheri A, Dressler J, Kotzsch M, Shakibaei M (2004) Interleukin-1beta-induced expression of the urokinase-type plasminogen activator receptor and its co-localization with MMPs in human articular chondrocytes. Histol Histopathol 19: 105-112.

Sheehy EJ, Mesallati T, Vinardell T, Kelly DJ (2015) Engineering cartilage or endochondral bone: a comparison of different naturally derived hydrogels. Acta Biomater 13: 245-253.

Shimizu S, Asou Y, Itoh S, Chung UI, Kawaguchi H, Shinomiya K, Muneta T (2007) Prevention of cartilage destruction with intraarticular osteoclastogenesis inhibitory factor/osteoprotegerin in a murine model of osteoarthritis. Arthritis Rheum 56: 3358-3365.

Simopoulou T, Malizos KN, Iliopoulos D, Stefanou N, Papatheodorou L, Ioannou M, Tsezou A (2007) Differential expression of leptin and leptin's receptor isoform (Ob$\mathrm{Rb})$ mRNA between advanced and minimally affected osteoarthritic cartilage; effect on cartilage metabolism. Osteoarthritis Cartilage 15: 872-883.
Stoddart MJ, Bara J, Alini M (2015) Cells and secretome - towards endogenous cell re-activation for cartilage repair. Adv Drug Deliv Rev 84: 135-145.

Studer RK, Georgescu HI, Miller LA, Evans CH (1999) Inhibition of transforming growth factor beta production by nitric oxide-treated chondrocytes: implications for matrix synthesis. Arthritis Rheum 42: 248-257.

Sze SK, de Kleijn DP, Lai RC, Khia Way Tan E, Zhao H, Yeo KS, Low TY, Lian Q, Lee CN, Mitchell W, El Oakley RM, Lim SK (2007) Elucidating the secretion proteome of human embryonic stem cell-derived mesenchymal stem cells. Mol Cell Proteomics 6: 1680-1689.

Tanabe K, Tokuda H, Takai S, Matsushima-Nishiwaki R, Hanai Y, Hirade K, Katagiri Y, Dohi S, Kozawa O (2006) Modulation by the steroid/thyroid hormone superfamily of TGF-beta-stimulated VEGF release from vascular smooth muscle cells. J Cell Biochem 99: 187-195.

Wang W, Zhuang H, Levitz CL, Fan H, Seldes RM, Tahernia AD, Brighton CT (1997) The increased level of PDGF-A contributes to the increased proliferation induced by mechanical stimulation in osteoblastic cells. Biochem Mol Biol Int 43: 339-346.

Wenke AK, Niebler S, Grassel S, Bosserhoff AK (2011) The transcription factor AP-2varepsilon regulates CXCL1 during cartilage development and in osteoarthritis. Osteoarthritis Cartilage 19: 206-212.

Wimmer MA, Grad S, Kaup T, Hanni M, Schneider E, Gogolewski S, Alini M (2004) Tribology approach to the engineering and study of articular cartilage. Tissue Eng 10: 1436-1445.

Wipff PJ, Rifkin DB, Meister JJ, Hinz B (2007) Myofibroblast contraction activates latent TGF-beta1 from the extracellular matrix. J Cell Biol 179: 1311-1323.

Zeddou M, Relic B, Malaise O, Charlier E, Desoroux A, Beguin Y, de Seny D, Malaise MG (2012) Differential signalling through ALK-1 and ALK-5 regulates leptin expression in mesenchymal stem cells. Stem Cells Dev 21: 1948-1955.

Zheng B, Ozen Z, Zhang X, De Silva S, Marinova E, Guo L, Wansley D, Huston DP, West MR, Han S (2005) CXCL13 neutralization reduces the severity of collageninduced arthritis. Arthritis Rheum 52: 620-626.

\section{Discussion with Reviewers}

Reviewer I: The discussion about NO is a strong section of the paper. However, some of the data indicate that NO could be good (inhibiting T-cell response?). Could the NO being produced by load be a good not bad thing? This was sort of alluded to in mentioning that it could play a role in mechanotransduction.

Authors: Further work is required to identify the role of $\mathrm{NO}$ in response to load and the effect that it has on MSC chondrogenesis, as NO may play a direct role in mechanotransduction and therefore for the generation of cartilage-like repair material in response to joint loading in vitro. A clear next step is to establish whether the NO plays a role in mechanotransduction, and whether it has an inhibitory effect on cartilage tissue development under 
these conditions and the extent to which NO levels can be modulated to improve chondrogenic outcomes.

Reviewer I: One limitation of the study is that the secretome is only analysed at a single time point. Clearly chondrogenesis is a dynamic process and we would anticipate the secretome would change. Furthermore, as noted there were instances where protein and gene data do not correlate, which (as discussed by the authors) is not unreasonable given this dynamic process and other reasons for a non-linear correlation between gene and protein. Looking forward, how could future experiments address the dynamic process of chondrogenesis and hypertrophic maturation?

Authors: The question of timing and the change in the secretome profile over time is a really important one. This study aimed to identify candidate molecules. The follow up would be to repeat this experiment with several time points (e.g. 3, 7, 14 and 21 days). The candidate molecules could then be investigated in more detail with assays such as ELISA. Alongside this, follow up studies based on the work presented here will allow for the characterisation of some of the markers identified in this work. These novel markers may also be useful for looking at the process of chondrogenesis over time alongside the 'classic' markers that are commonly used in the field..
Reviewer II: Please explain why factors were selected for RT-PCR on the basis that they are soluble proteins.

Authors: This decision was made in order to remove possible differences in the data as a result of changes to turnover (including internalisation) and the shedding of membrane bound proteins (in particular in response to load) which may further cloud the differences between the media protein content and mRNA levels as determined by RT-PCR.

Reviewer II: What further experiments do you suggest to investigate the role of NO in load-induced chondrogenesis? Authors: This is something we are really excited about. The first thing to establish is how load and NO are related. In order to do that, we would load in the presence of an NOS blocker. If NO is involved in mechano-transduction then the block may disrupt chondrogenesis. If blocking NO does not affect chondrogenesis and NO is being produced as part of a separate process, the benefit of blocking NO production on chondrogenesis could be investigated, to see if you can get a better chondrogenic outcome.

Editor's Note: Scientific Editor in charge of the paper: Chris Evans. 